\title{
Identification of Quarry Blasts Aided by Infrasound Data
}

\section{Csenge Czanik, ${ }^{1}$ Márta Kiszely, ${ }^{1}$ Péter Mónus, ${ }^{2}$ Bálint Süle, ${ }^{1}$ and István Bondár ${ }^{2}$ (D}

\begin{abstract}
We present our analysis of the detections from the Piszkés-tető, Hungary infrasound array that has been operational since May 2017. We introduce an automatic search method to associate infrasound detections with a preliminary list of explosions detected by the seismic network. Once infrasound detections are associated with seismic events, we relocate the events using both the seismic arrival time and infrasound azimuth observations. We validate our methodology on ground truth events, i.e., explosions confirmed by the mine operators. We demonstrate that seismo-acoustic locations are able to identify the source of explosions even for closely spaced quarries. The discriminative power of the infrasound azimuth is strongest at near-field distances, where local and regional seismic discrimination methods have the most difficulties.
\end{abstract}

Keywords: Seismology, infrasound, discrimination, seismoacoustic location.

\section{Introduction}

Separating natural seismicity from man-made events is necessary to study tectonic processes and to estimate seismic hazard and risk in a region. One of the major drivers behind seismic discrimination studies is the need to distinguish between earthquakes and nuclear explosions in order to provide a reliable verification regime for the Comprehensive NuclearTest-Ban Treaty (Blandford, 1977; Bowers \& Selby, 2009; Richards \& Zavales, 1990). Studies that combine seismic and infrasound signals significantly improve source identification and constrain propagation path effects (Che et al., 2011, 2019; Ford \&

1 ELKH Institute of Earth Physics and Space Science, Kövesligethy Radó Seismological Observatory, Budapest, Hungary.

2 ELKH Research Centre for Astronomy and Earth Sciences, Institute for Geological and Geochemical Research, Budaörsi út 45, Budapest 1112, Hungary. E-mail: bondar.istvan@csfk.org
Walter, 2015; Gibbons et al., 2007, 2019; Sorrells et al., 1997; Stump et al., 2002). The association of infrasound signals with seismic signals not only can provide additional constraints on the source type, but can further complement seismic data by providing a more precise back-azimuth estimate and thus give reliable event direction for purposes of location.

The first infrasound array in Hungary (PSZI) began operations on 25 May 2017. One of the main motivations for the new station is to aid in the discrimination of natural and anthropogenic seismicity. Explosions occurring at or near the surface not only generate seismic waves, but the energy propagates large distances in the atmosphere in the form of infrasonic waves. The infrasound array in Piszkéstetö was intentionally designed so that it is co-located with a seismic station. Hence, the infrasound array and the seismic station together can serve as a seismo-acoustic receiver. Combined with wellestablished seismic discrimination techniques, the infrasound records will help us to routinely distinguish earthquakes from explosions.

The Hungarian National Seismological Network operated by the Kövesligethy Radó Seismological Observatory (KRSZO), Geodetic and Geophysical Institute of the Research Centre for Astronomy and Earth Sciences, consists of 15 permanent and 13 temporary broadband seismological stations (Fig. 1). The events are published annually in the Hungarian National Seismological Bulletins (Gráczer et al. 2018, 2019). Hungary is characterized by low-tomoderate seismicity. However, approximately two thirds of the seismically recorded events are anthropogenic events, such as quarry blasts and mine explosions. Hence, to study the natural seismicity of the country and produce reliable seismic hazard estimates, it is important to identify and separate natural events from anthropogenic ones. 


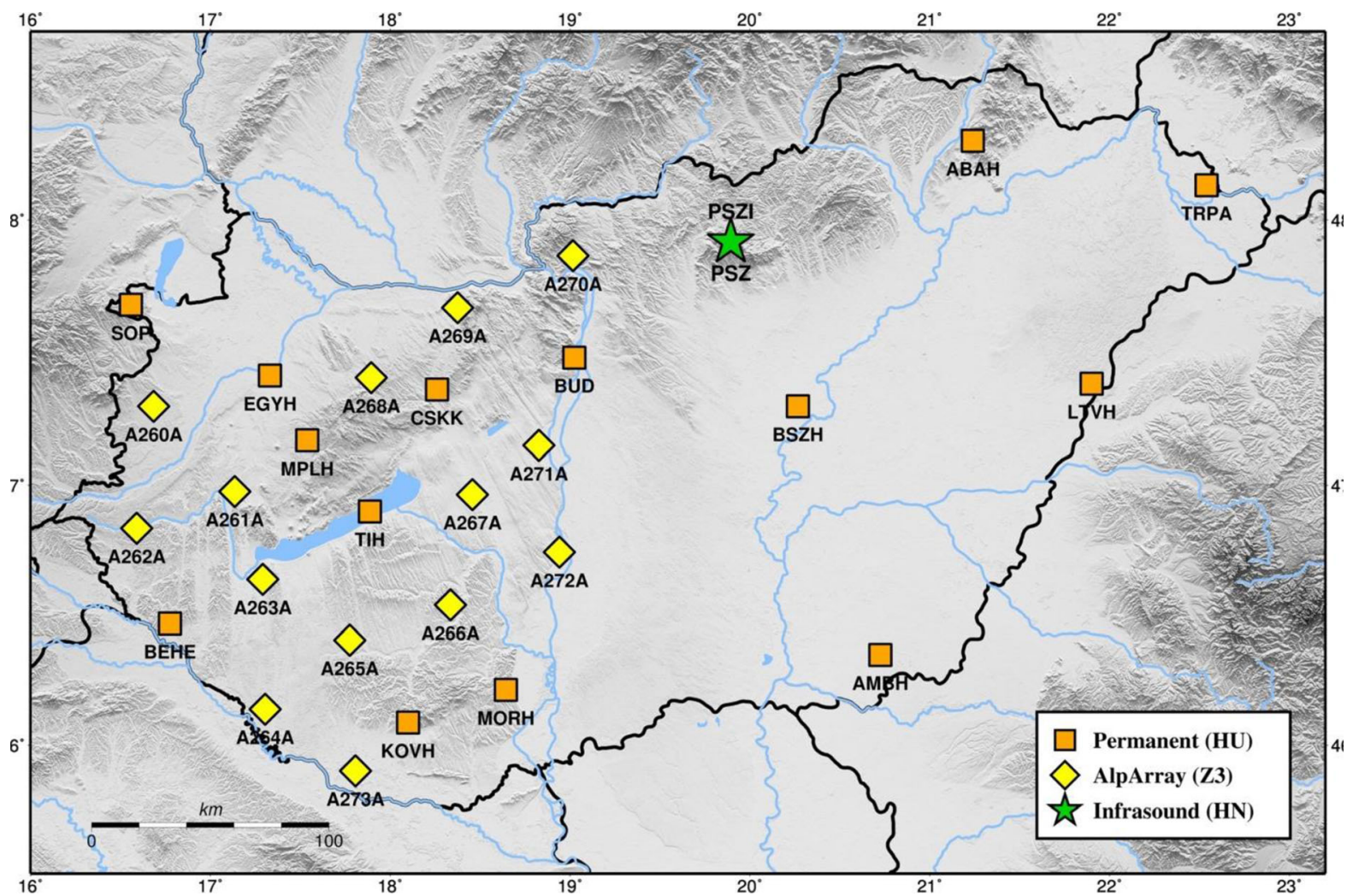

Figure 1

Permanent (orange) and temporary (yellow) seismic networks operated by the Kövesligethy Radó Seismological Observatory between 2017 and 2019. Green star denotes the location of the PSZI infrasound array co-located with PSZ permanent seismic station

Discrimination between natural earthquakes and mine explosions is performed manually by an experienced analyst based on seismological data as well as reports by the mining agencies.

Figure 2 shows the percentage of earthquakes and explosions in the earthquake catalog of Hungary for each year. Since the PSZI array has started its operation increased interest turned towards identifying mining explosions in the KRSZO, and as a result of careful analysis of seismic data completed with infrasound detections, the ratio of identified explosions among the seismically recorded events has significantly increased.

In this paper we show that infrasound detections play an important role in identifying quarry blasts, especially at local distances where there are no reliable established seismic discrimination methods.

\section{The PSZI Infrasound Array}

The first Hungarian infrasound array, PSZI was installed in May 2017 as the first station of the Hungarian National Infrasound Network (HNIN, https://doi.org/10.14470/UA114590). It is located in North Hungary, on Piszkés-tető peak in the Mátra mountains, at 930-m elevation. The array consists of four elements and has an aperture of approximately $250 \mathrm{~m}$. All elements are equipped with SeismoWave MB3d microbarometers. The central element of the array is co-located with a broadband three-component seismological station (PSZ) jointly operated by GEOFON and KRSZO. The site is located in temperate mixed forest with relatively dense undergrowth that helps to further reduce environmental noise.

All infrasound data are acquired in real time in miniSEED format by the HNIN data center located at 


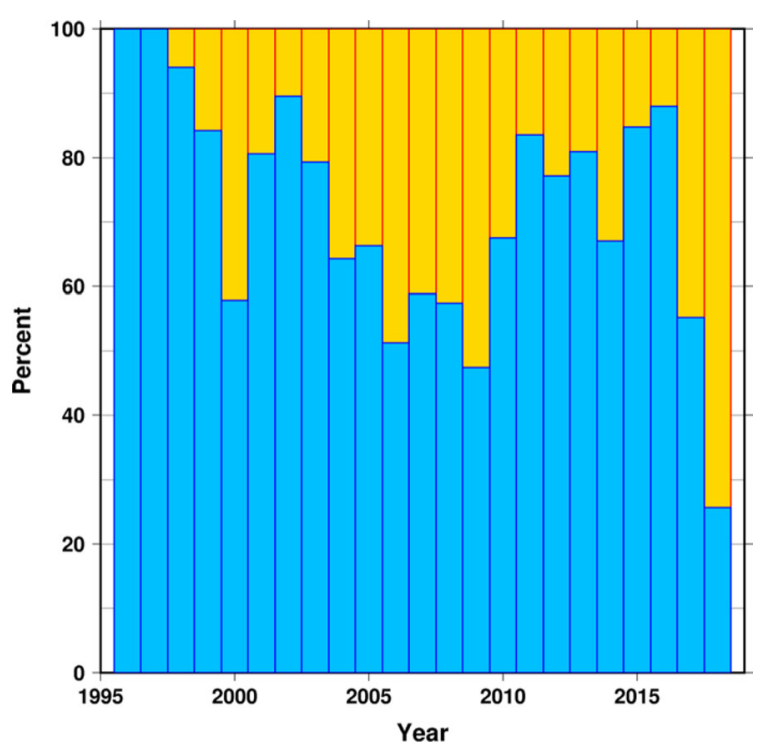

Figure 2

Relative occurrence of natural (blue) and anthropogenic (yellow) events in the Hungarian event catalog between 1996 and 2019. The number of events identified as explosion has been increased since the operation of the PSZI infrasound array has begun

the Kövesligethy Radó Seismological Observatory, Budapest, Hungary. The sampling rate for the infrasound BDF channels is set to $100 \mathrm{~Hz}$. The array is registered at the International Registry of Seismographic Stations with the FDSN network code HN. For data acquisition we use SeisComp3 (http://www. seiscomp3.org) and for data processing we use DTKPMCC, based on the progressive multichannel correlation method (PMCC, Cansi, 1995), both software being part of the CTBTO NDC-in-a-box software package.

The array detects signals from various sources including microbaroms from the Northern Atlantic Ocean and the Black Sea, regional thunderstorms (Pásztor et al., 2020), sonic booms, volcanic eruptions, aircraft passing above the array, bolides (Kereszturi et al., 2020), industrial and accidental explosions (Koch et al., 2020). Seismo-acoustic and acoustic-only events detected by the array are published annually in the Hungarian Seismo-Acoustic Bulletin (Bondár et al., 2019, 2020).

\section{Mining Explosions}

There are a number of mines and quarries in Hungary and neighboring countries that blast regularly. Many of these explosions are detected by the seismic network, and some also by the PSZI infrasound array. We will use these events to develop and test a method for improving the discrimination of explosions from earthquakes. First we study the array's ability to detect explosions from the mines around the country.

The events detected by the seismic network are classified as explosions by an experienced analyst who also associates them with individual mines. Note that some of the mine operators report their explosions, so these are regarded as ground truth events.

For the infrasound analysis we use the preliminary list of explosions from the seismic analysis. The list typically contains many more events than those published in the Hungarian National Seismological Bulletin (HNSB) as many of these explosions are detected by only two seismic stations, or due to large uncertainties they are screened out from the HNSB. However, the seismic signals show evidence of an explosion, and this information can still be used for testing the infrasound detections.

We consider the mines from which at least five explosions have been recorded at PSZI between 2017 May and 2019 December. Altogether 1500 explosions have been recorded from these mines by the seismological network, with magnitudes between 0.5 and 2.5.

Based on the seismic event list, we search for infrasound arrivals in the expected arrival time and back-azimuth ranges. The infrasound data is uniformly processed with the PMCC method (Cansi, 1995) for the entire period to determine the horizontal trace velocity and back-azimuth of the signals. The processing parameters are optimized for broadband observation, i.e., for detecting signals from various sources in a broad frequency range. Parameters used for PMCC processing of the data are shown in Table 1.

For each event in the seismic event list, we compute the expected arrival time of the signal based on the seismic location and origin time, using a nominal $c=300 \mathrm{~m} / \mathrm{s}$ propagation velocity. The 
Table 1

Parameters used for PMCC processing of PSZI data

\begin{tabular}{ll}
\hline Detection range & $0.09-7.1 \mathrm{~Hz}$ \\
Window length & $60-12.35$ \\
Window overlap & $95 \%$ \\
Consistency & 0.02 \\
Filter & Chebyshev \\
Azimuth tolerance & $3^{\circ}$ \\
Family size & $100-2000$ pixels \\
\hline
\end{tabular}

detections for each event are searched in a 6-minlong time window around the expected arrival time.

The expected back-azimuth is also computed based on the seismic location. Seismic location uncertainties are typically not greater than $10 \mathrm{~km}$ in the HNSB. However, in some cases in the preliminary event list used for this work, location errors can be larger than $20 \mathrm{~km}$, due to poor station coverage and suboptimal network geometry. At small distances from PSZI, such location errors can cause large backazimuth deviations, so it is important to correctly set the azimuth window for automatic search for detections. For instance, $20 \mathrm{~km}$ location error at a distance of $10 \mathrm{~km}$ from the station (which is the distance of the nearest quarry, Gyöngyössolymos) can result in a back-azimuth deviation up to $75^{\circ}$, while the same location error at $60 \mathrm{~km}$ distance causes only a $10^{\circ}$ deviation. Azimuth windows for matching detections with the seismic events are adapted to the distance between seismic epicenter and PSZI station. The azimuth range for the search is defined as

$$
\mathrm{BAZ}_{\text {err }}=2 \arcsin (\mathrm{d} \Delta / 2 \Delta),
$$

where $\Delta$ is the epicentral distance and $\mathrm{d} \Delta$ is the estimated location uncertainty. When this value is lower than $15^{\circ}$ for $\Delta>40 \mathrm{~km}, \mathrm{BAZ}_{\mathrm{err}}=15^{\circ}$ value is used uniformly. In the extreme case when the location uncertainty is larger than twice the epicentral distance, the azimuth window is set to $180^{\circ}$, and the time window is checked for detections regardless of the back-azimuth values. Time and back-azimuth windows for automatic search are intentionally chosen large enough to have false detections rather than missed events. For this reason, $20 \mathrm{~km}$ location error is used for calculating back-azimuth windows, even if it is much more than the typical location errors for most events. Minimum back-azimuth window and time window are set based on experiments to obtain the best result. The matching detections are always manually checked again by an experienced analyst to confirm that they are really a signal from a quarry blast.

Sometimes signals from other sources (e.g. microbaroms) match the search criteria, but they can be easily screened out by the analyst by the shape of waveforms and PMCC detections. An example is shown on Fig. 3 for a typical signal of an explosion in a nearby mine, and microbarom signal from similar direction.

The search method was applied for the data set of 1500 seismically detected explosions. Out of the 1500 events, 319 were detected by the PSZI infrasound array. Figure 4 shows the location of the quarries where the radius of the circles is proportional to the number of explosions detected seismically, and the color shows the percentage of explosions recorded by the infrasound array. The geographical distribution of the mines and the number of explosions at each mine is uneven, which makes it difficult to conduct comprehensive analysis of detectability based on location. However, there are some trends as a function of distance from PSZI.

Figure 5a shows the detection rates as a function of distance from PSZI regardless of the azimuths, in $10 \mathrm{~km}$-wide zones, defined as the total number of explosions detected by the infrasound array in the zone divided by the total number of seismically detected explosions in each zone. A more detailed table with event numbers and detection rates for each mine are listed in the Appendix. In the vicinity of the array, detection rates are the highest; up to $40 \mathrm{~km}$ the detection rate is above $60 \%$. Between 40 and $90 \mathrm{~km}$ the detection rates decrease, varying between 20 and $55 \%$. In the range between 90 and $190 \mathrm{~km}$, the detection rates are very low, well below $20 \%$, and beyond $190 \mathrm{~km}$ the rates are higher again. These trends can be explained by the propagation patterns of the infrasound waves.

Infrasound propagation is controlled by wind speed and direction and by temperature along the path it travels from source to receiver. These factors vary in time and space and cause the infrasound waves to refract at different altitudes (Drob et al., 


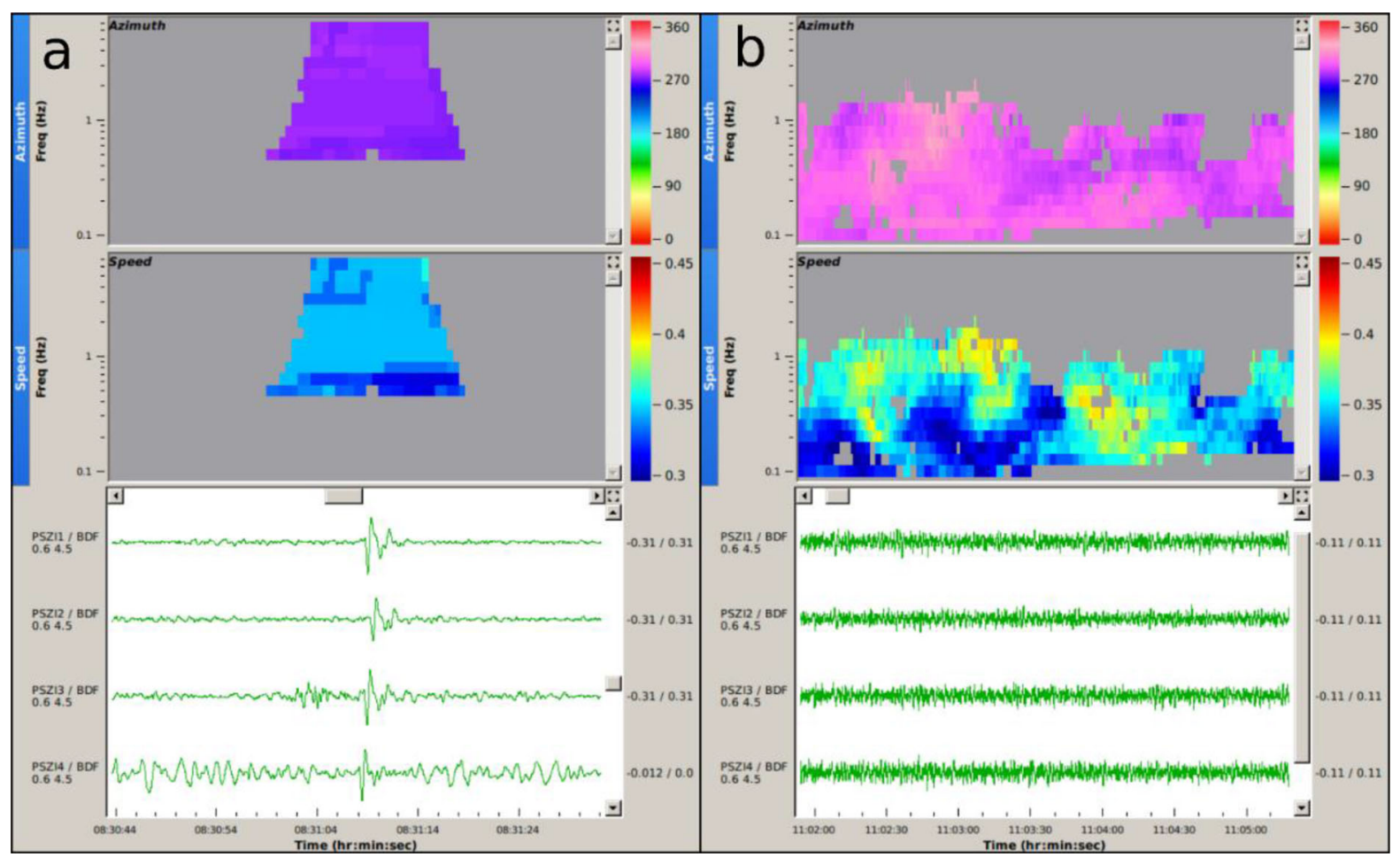

Figure 3

The lower blocks show infrasound waveforms recorded by the four elements of PSZI, filtered with a 0.6-4.5 Hz bandpass filter; the top and middle blocks show the corresponding PMCC detections, colored by azimuth and apparent velocity, respectively. a is an example for a real signal of an explosion at Szanda mine located $35 \mathrm{~km}$ from the PSZI array in the north-western direction (269 $9^{\circ}$ back-azimuth), which is the typical direction of microbaroms from the North Atlantic Ocean. b Shows microbarom signals from a similar direction $\left(287-290^{\circ}\right)$, thus matching the search criteria and marked as detection by the automatic search. The two signals can be easily distinguished by the analyst

2003). In our distance range of interest (up to $300 \mathrm{~km}$ ) we can expect phases reflected in the troposphere and the stratosphere, as seen in previous studies (e.g. Fuchs et al., 2019; Koch \& Pilger, 2020; Schneider et al., 2018) Observed infrasound phases coming from different paths in the atmosphere can be distinguished based on their celerities (Kulichkov, 2000; Negraru et al., 2010), defined by the travel time of the signal divided by the horizontal distance of the source and the receiver.

Figure $5 \mathrm{~b}$ shows the celerity of each detected explosion as a function of its distance from PSZI. The plot shows a nice grouping of the events that can be associated with different phases. In the $0-40 \mathrm{~km}$ range the events have high celerities, mostly above $330 \mathrm{~m} / \mathrm{s}$, which according to Negraru et al. (2010) can be associated with phases reflected at heights up to $1 \mathrm{~km}$. Note that in this short range the location errors can cause large errors in the calculation of celerity, which explains the significant scatter in the celerity values.

In the $40-90 \mathrm{~km}$ zone the celerity values are less scattered and are all between 310 and $360 \mathrm{~m} / \mathrm{s}$, which suggests that these are detections from tropospheric and lower-altitude turning points. In the range beyond $190 \mathrm{~km}$, most of the events have celerities between 280 and $310 \mathrm{~m} / \mathrm{s}$ which is the typical celerity range for stratospheric arrivals.

In the zone between 90 and $190 \mathrm{~km}$, where detection rates are very low, celerity values show high variability. While there is a group of events in the typical celerity range of tropospheric phases $(310-330 \mathrm{~m} / \mathrm{s})$, another group is also present with much lower celerities and large scatter; these arrivals can be associated with stratospheric phases according to Nippress et al. (2014). The low detection rates 

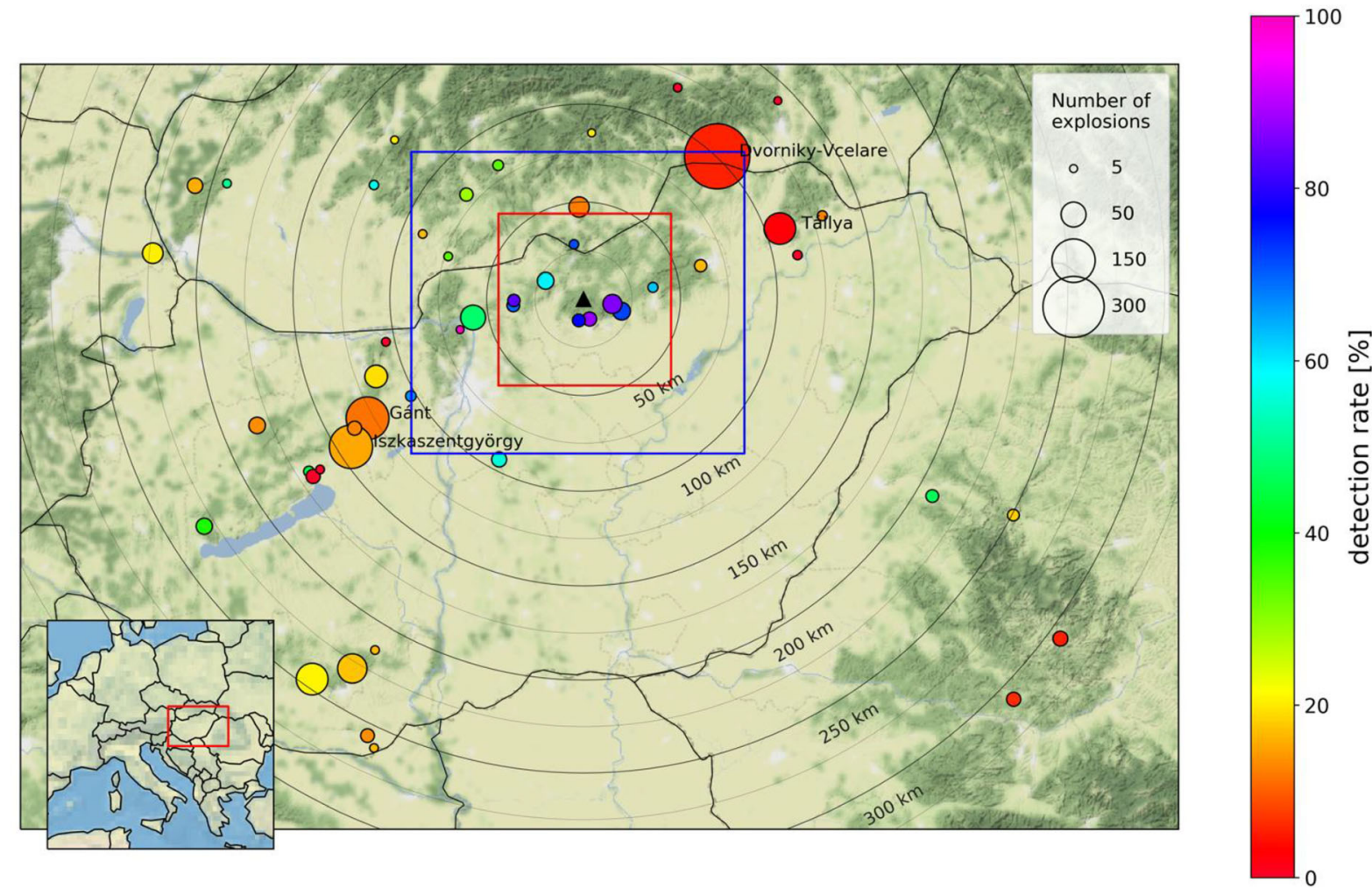

Figure 4

Surface explosions from quarries and mines detected by the PSZI infrasound array (triangle). The size of the circles at the mine locations is proportional to the total number of events color-coded by the detection rate at PSZI. Blue and red squares mark the areas shown on Figs. 6 and 7 , respectively
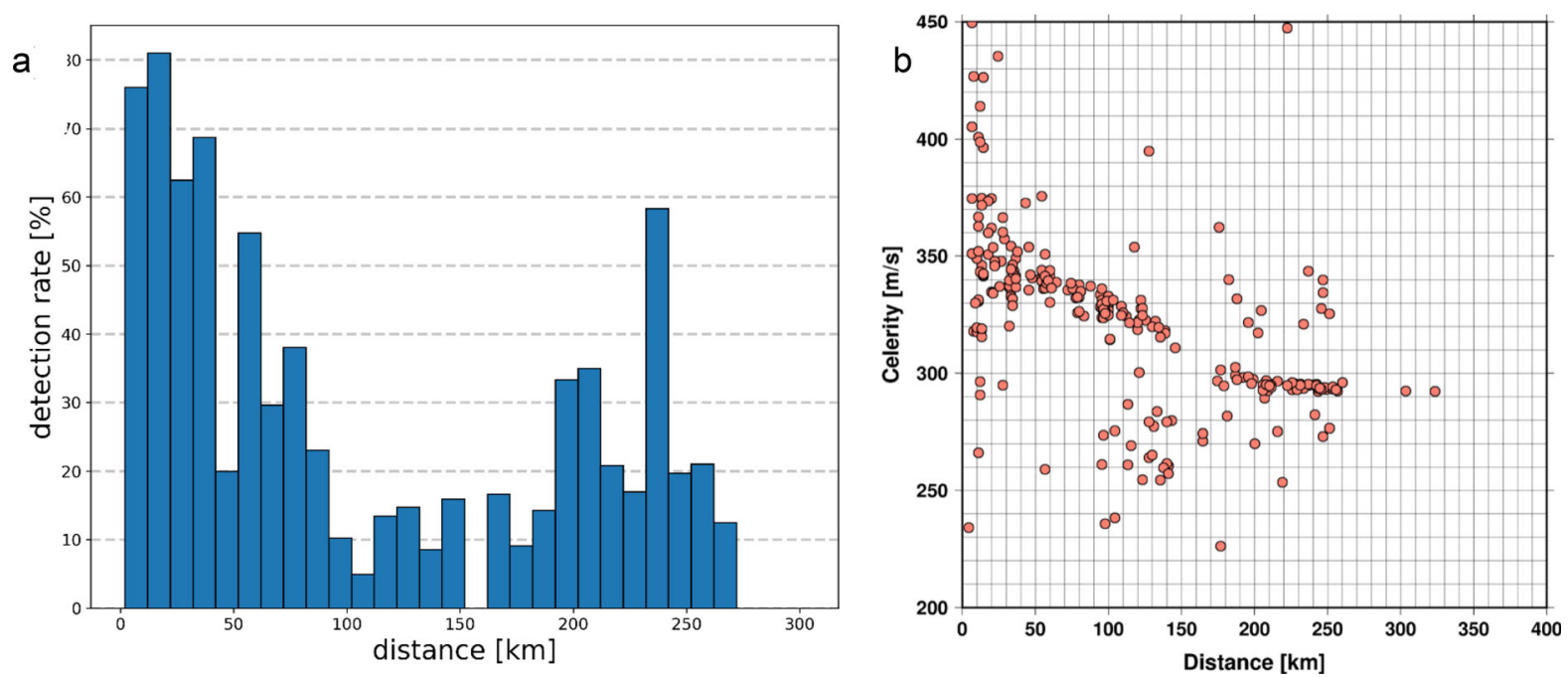

Figure 5

a Detection rates and $\mathbf{b}$ celerity of the detected event as a function of distance from PSZI 
suggest that most of the time, the $90-190 \mathrm{~km}$ range is in a geometrical shadow zone for PSZI between tropospheric and stratospheric phases; however, the temporally varying atmospheric conditions sometimes still allow some signals to reach PSZI from this zone, through different ducts. Note that the most active mines are located in this zone, namely Iszkaszentgyörgy, Gánt, Tállya and Dvorniky-Vcelare. Explosions from these four mines constitute 28\% of all the events (419 explosions), which explains the relatively low overall detection rate. There are not enough events in our data set for more detailed analysis of the detection patterns, and this will be the focus of further studies when more events will be accumulated.

\section{Near-Field Events}

In order to use the automated search as a base for selecting anthropogenic events from natural ones, we first apply it to a set of events that contain both explosions and earthquakes. To test the efficiency of the method, we use a smaller amount of data and check every single event manually, and determine whether the automatic search result was correct. In other words, in the entire data set, only those events were checked manually where the automated search found a matching signal. Events without a matching signal were screened out immediately, although a few detections might have been lost this way.

For this test we chose the area with the highest detection rates: the $60 \mathrm{~km}$-radius circle around the array where $60 \%$ of the events were detected. This region also included natural seismic events detected by the seismic network in the same time period (May 2017-December 2019), which allowed us to test and validate the automated search.

We use the events from the Hungarian National Seismological Bulletin for 2017 and 2018 (HNSB, Gráczer et al., 2018, 2019), completed with the preliminary event list for 2019, which was not published at the time of writing. Note that the preliminary seismic locations in 2019 rely on picks from the permanent network, as the picks from the much denser temporary deployments will only be added during the final review. Hence, the quality of the
2019 seismic locations is somewhat lower than those from 2017 to 2018.

Figure 6 shows the data set for 267 events within a distance of $60 \mathrm{~km}$ from the PSZI array between 1 July 2017 and 31 December 2019. Of these, 227 events are classified as known or suspected explosions and 44 events are identified as earthquakes, mostly from a sequence of small earthquakes that occurred $45 \mathrm{~km}$ south-east of PSZI in August 2019 with magnitudes of 0.5-2.5.

The automatic search results are summarized below.

- One hundred and twenty-two explosions were detected by the infrasound array and also correctly found by the automatic search.

- Ten events were detected by the infrasound array but missed by the automatic search. It was in most cases due to large seismic location errors, even larger than $20 \mathrm{~km}$ in the case of events detected by only two seismic stations.

- Twenty false detections for explosions: detections found in the time-azimuth window that did not originate from the actual explosion. Many of them are from the Vác and Nagylóc mines, located at 261 and 296 azimuths from PSZI, respectively, i.e., in the direction from where North Atlantic microbaroms are detected throughout the winter period. Microbarom detections may satisfy the automatic search criteria, while the real signal from the explosion is hidden in the microbarom signals or lost due to atmospheric conditions. In other cases, detections made from some unknown source of continuous noise or detections from aircraft passing above the station fit the search criteria.

- Sixty-eight explosions were not detected by the infrasound station and no matching detection was found.

- One explosion was found in the published bulletins previously classified as earthquake: a blast from the Szanda mine, with magnitude 1.6. In other words, the approach worked for separating an explosion from an earthquake.

- Seven natural earthquakes had a matching detection. All of them were events from the earthquake series that occurred in August 2019 near the town of Tenk, approximately $133^{\circ}-135^{\circ}$ from PSZI, 


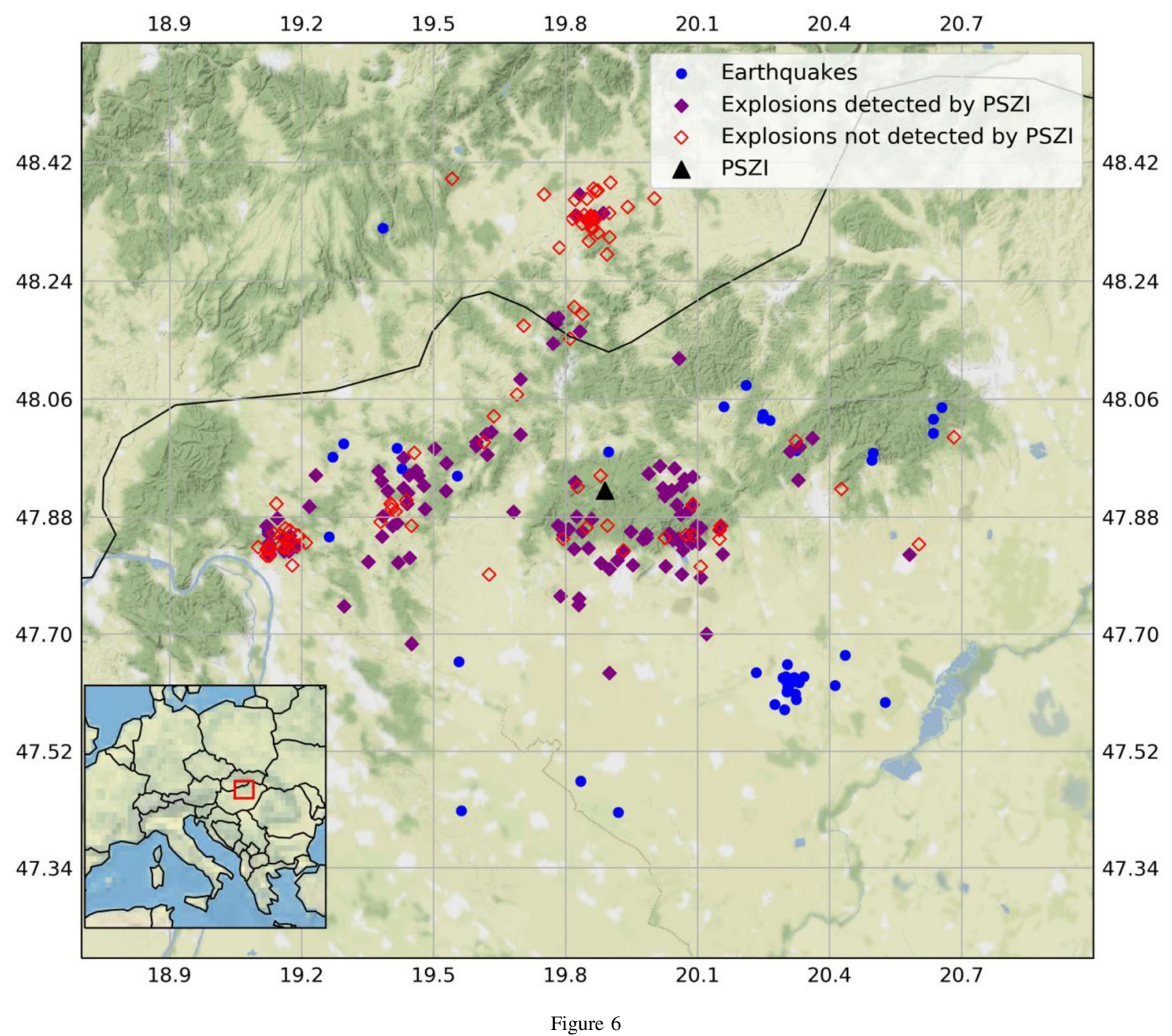

Near-field events around PSZI (triangle) between 1 July 2017 and 31 December 2019. Circles indicate the locations of earthquakes, filled diamonds are explosions detected by PSZI, and empty diamonds denote explosions that were not detected by PSZI

which is almost exactly the direction of the Mátra Power Plant, located $20 \mathrm{~km}$ from PSZI at $137^{\circ}$, that continuously produces detections throughout the summer period, thus satisfying the search criteria for the Tenk earthquakes. Manual analysis confirmed that the detections are indeed industrial noise from the Mátra Power Plant and thus can be considered false alarms.

- Thirty-six natural earthquakes did not have any matching signal.

- At the time of two events, the infrasound array was not working, and no infrasound data are available.
Table 2

Confusion matrix of the automated search results

\begin{tabular}{|c|c|c|}
\hline & Detected by PSZI & Not detected by PSZI \\
\hline $\begin{array}{l}\text { Found by } \\
\text { auto- } \\
\text { search }\end{array}$ & $\begin{array}{l}\text { True detections: } \\
122 \text { explosions } \\
(46 \%)\end{array}$ & $\begin{array}{l}\text { False detections: } 21 \\
\text { explosions/7 earthquakes } \\
(11 \%)\end{array}$ \\
\hline $\begin{array}{l}\text { Not found } \\
\text { by auto- } \\
\text { search }\end{array}$ & $\begin{array}{l}\text { Missed detections: } \\
\quad 10(4 \%)\end{array}$ & $\begin{array}{l}\text { No detectable infrasound: } 68 \\
\text { explosions/36 earthquakes } \\
(39 \%)\end{array}$ \\
\hline
\end{tabular}


Table 2 summarizes the results in a confusion matrix. Our automatic search correctly associated infrasound detections to seismic events in $46 \%$ of the cases, did not make an association when there was none in $39 \%$ of the cases, missed $4 \%$ of the events and made false associations in $11 \%$ of the cases. Hence, the true positives and true negatives make up $85 \%$ of the cases, while the false negative and positives constitute $15 \%$. Note that the table does not include the event that was previously mistakenly identified as an earthquake and the two events where no infrasound data was available.

\subsection{Seismo-acoustic Locations}

The association of explosions with the origin mines is based primarily on seismic location, occasionally complemented with ground truth information from the mining authorities. However, the report from the mines may only arrive several months after real time; therefore, the association to the mines strongly depends on our experienced analyst. Our objective is to develop a method for the automatic association of events to mines.

We focus on the close vicinity of the PSZI array, where just a few kilometers of location errors may result in large deviations in back-azimuths. In this region there are several mines that are separated from each other within the uncertainty of seismic location. Hence, it is difficult to clearly identify exactly which mine was the source of the event. Seismic discrimination techniques have very limited use at very local distance ranges of a few tens of kilometers (Kintner et al., 2020; O'Rourke et al., 2016). However, in such a small distance, the resolving power of the infrasound azimuth measurements can have a significant effect on event locations. We relocate the events using both seismic and infrasound observations and show that the improved locations due to the contribution of infrasound data can be used to correctly identify the mine that carried out the blast. Finally, we validate the result using the available ground truth information.

To relocate the events, we use the location algorithm (Bondár \& McLaughlin, 2009) originally implemented at the International Seismological Centre (Bondár \& Storchak, 2011) and further developed as iLoc (Bondár et al., 2018). iLoc is able to use arrival time, back-azimuth and slowness measurements from seismic, hydroacoustic and infrasound stations, and therefore it is a natural candidate to obtain seismo-acoustic locations. Infrasound azimuth measurements are typically very accurate (Che et al., 2019); therefore, iLoc assigns a much smaller a priori measurement error estimate of $1^{\circ}$ to infrasound azimuth observations than to seismic azimuths, and a much larger a priori measurement error estimate to infrasound travel times. The a priori measurement error estimates in effect down-weight infrasound travel times so that they do not contribute to the location, while the infrasound azimuth measurements have a weight comparable to the first arriving $\mathrm{P}$ phases in the location.

Figure 7 shows the location of PSZI and eight selected mines (Gyöngyössolymos, Gyöngyöstarján, Recsk, Kisnána, Egerbakta, Bercel, Szanda, Nagylóc) to demonstrate the value of infrasound-aided relocation of seismic events for identifying the source mines. Squares indicate the location based on seismic data only. Circles show the seismo-acoustic locations using both seismic and infrasound data. Owing to the

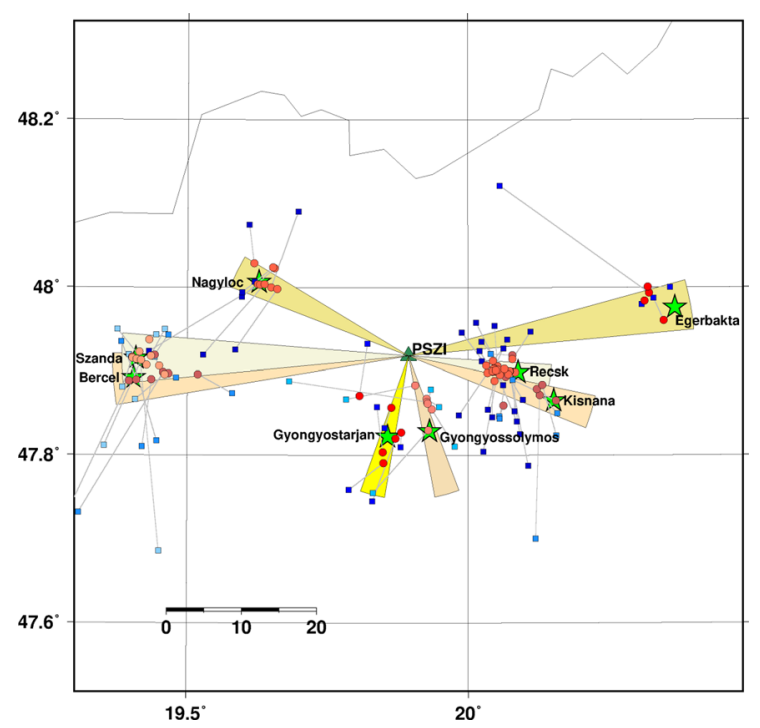

Figure 7

Seismic (squares) and seismo-acoustic (circles) locations of mine explosions. Besides the seismic arrival times, iLoc uses the infrasound azimuth measurements in the seismo-acoustic locations. Stars indicate the quarries; the search range in azimuth for each mine is indicated by wedges 
use of infrasound azimuth in the location, the seismoacoustic locations significantly reduce the mislocations.

The two closest mines to PSZI are Gyöngyössolymos and Gyöngyöstarján, both located approximately $10 \mathrm{~km}$ from PSZI and $5 \mathrm{~km}$ from each other. Gyöngyössolymos is at $163^{\circ}$; Gyöngyöstarján is at $197^{\circ}$ from PSZI. The back-azimuth of the detected infrasound signal can easily discriminate between these two mines.

Szanda and Bercel are located about $35 \mathrm{~km}$ to the NW from PSZI, at $269^{\circ}$ and $265^{\circ}$, respectively, and separated by $2.5 \mathrm{~km}$. Nagylóc is located $22 \mathrm{~km}$ and $296^{\circ}$ from PSZI, roughly $19 \mathrm{~km}$ from Bercel and Szanda. Events from these mines are often detected only by three seismic stations, and due to the large azimuthal gap, the seismic location errors often exceed $20 \mathrm{~km}$. Due to the large location errors explosions from Nagylóc are also often associated with Szanda or Bercel and vice versa. Although the difference of back-azimuths is very small for these mines, infrasound data can help to reduce uncertainty of locations and determine the source of the explosion.

Recsk and Kisnána are also two mines with a relatively small separation of $6 \mathrm{~km}$ from each other and overlapping back-azimuth windows. Being well within the typical seismic location uncertainties, the explosions are often wrongly associated with one of these mines. Improved locations due to the infrasound back-azimuth helps in correcting the misassociations.

To validate our method, we tested the eventmine association process with the available groundtruth information. First, we associated the mine located nearest to the seismic-only location of the event. After relocating the events by adding the azimuth from the infrasound detection, we associated again the nearest mine with the new, seismo-acoustic location, and compared with the ground truth information reported by the mines.

Of the 67 events in Fig. 7, 49 ground-truth events were reported by the mine operators. Out of the 49 events, 33 had been already associated with the correct mine based on the seismic-only location, 32 of them remained correctly associated with the seismo-acoustic location (however, location errors significantly decreased), and one event was reassociated from the right mine (Bercel) to a wrong one (Szanda). Sixteen events were originally associated with wrong mines by the seismic locations. Fourteen of them were correctly reassociated by the seismoacoustic location, and two events were still reassociated with the wrong mine. Altogether, based on the seismo-acoustic location, out of 49 events, 46 were correctly associated with their real source, and only three were associated with wrong mines.

Figure 8 shows the cumulative distribution of mislocations of the seismic and seismo-acoustic locations of GT events. The median mislocation is reduced from 6.1 to $2.6 \mathrm{~km}$, and at the $90 \%$ percentile level it is reduced from 13.4 to $4.3 \mathrm{~km}$.

\section{Discussion}

Our results show that infrasonic data is a very effective tool to complement seismic data for discrimination of natural earthquakes from surface explosions. The method is the most effective in the

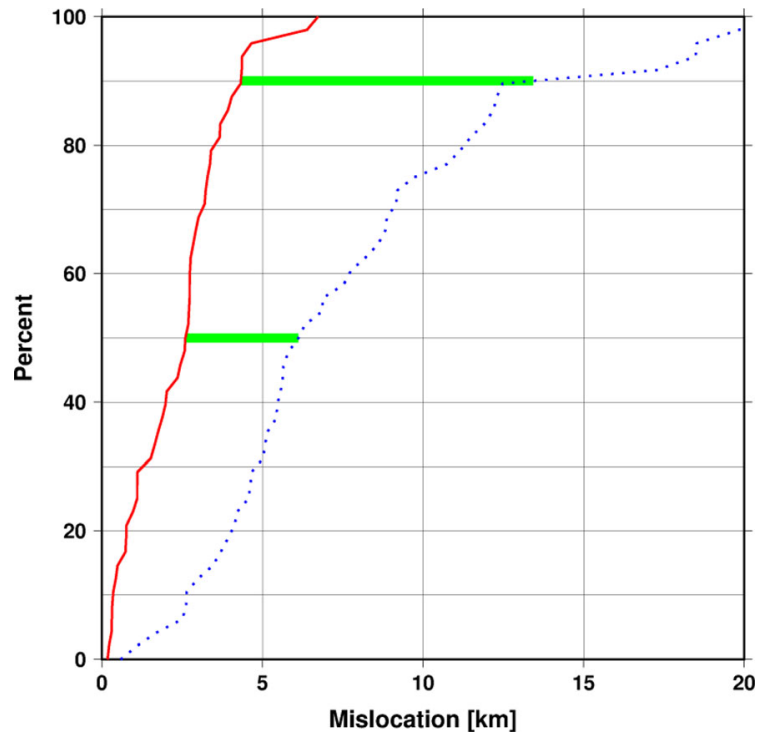

Figure 8

Cumulative distribution of mislocation of GT mine explosions of seismic (dotted line) and seismo-acoustic (solid line) locations with iLoc. The seismo-acoustic locations use the seismic arrival times together with the infrasound azimuth measurements. The thick horizontal lines emphasize the location improvements at the median and the 90th percentile levels 
distance range of direct arrivals, within a few tens of kilometers of the infrasound array, but it can still contribute to the analysis of more distant events as well, depending on atmospheric conditions.

Mining explosions are typically low-magnitude seismic events, detected by only a few seismic stations, and the low number of phases used in the location often result in poor location quality. Combining seismic arrival times with infrasound backazimuth measurements can significantly improve locations, especially at local distances. Better locations also help associating seismo-acoustic events to mines and quarries. These explosions produce more than a hundred seismo-acoustic events with accurate locations and they are published annually in the Hungarian Seismo-Acoustic Bulletin (Bondár et al., 2019, 2020), including the ground-truth events confirmed by the mines. Our bulletin will contribute to the European Infrasound Bulletin (Pilger et al. 2018).

Our procedures can be further improved by finetuning the PMCC processing parameters so that they are optimized for detecting explosions, instead of using our general-purpose parameters for PMCC. As data accumulate in time, we will be able to analyze seasonal trends in the detection of stratospheric phases from events that occur far (beyond $200 \mathrm{~km}$ ) from the infrasound array. Ground truth events will also allow us studying regional propagation conditions (Gibbons et al., 2019; Smets et al., 2015).

Finally, the PSZI array is not only useful for detecting local events but also contributes to the European and global infrasound network. The Central and Eastern European region has been sparsely covered by infrasound stations for many years, before the deployment of PSZI and other stations in the Central and Eastern European Infrasound Network (CEEIN; Czanik et al., 2019). PSZI has a central location in the region, and therefore significantly improves the coverage of the European network in the region (Le Pichon et al., 2008, 2012).

\section{Conclusions}

We have demonstrated that infrasonic data can be a very useful addition to complement seismic data for discrimination between natural earthquakes and surface explosions. Our automated search method that associates infrasound detections with seismic events gives reasonably robust results, being correct $85 \%$ of the time. The use of azimuth observations of an infrasound array together with travel times of seismic phases in a state-of-the-art location algorithm not only allows us to discriminate between earthquakes and explosions, but also helps to identify the source of the explosion with high confidence, even in the case of closely spaced mines. The power of the method is most effective in the distance range of direct infrasonic arrivals, i.e., within $50-100 \mathrm{~km}$ of the infrasound array, where local and regional seismic discrimination methods have the most difficulty in distinguishing between explosions and earthquakes.

\section{Acknowledgements}

We thank the anonymous reviewer for the comments that helped to improve the paper. We are grateful to Alexis Le Pichon (Commissariat à l'énergie atomique et aux énergies alternatives, CEA) for his comments on an early version of the manuscript and Kristian Csicsay (Earth Science Institute of the Slovak Academy of Sciences) for giving us information on quarry blasts in Slovakia. We thank GeoRisk Earthquake Engineering Ltd for making available their seismological stations (https://doi.org/10.7914/SN/ $\mathrm{HM}$ ) and the Hungarian National Seismological Network (https://doi.org/10.14470/UH028726) to create the preliminary list of explosions. The reported investigation was financially supported by the National Research, Development and Innovation Fund (K128152).

\section{Funding}

Open access funding provided by ELKH Research Centre for Astronomy and Earth Sciences. This work was supported by the National Research, Development and Innovation Fund (K128152), Hungary. 


\section{Code availability}

We used the CTBTO NDC-in-a-box software (SeisComp3, PMCC, DTK-Diva) distributed by the Comprehensive Nuclear-Test-Ban Treaty Organization among the State Parties. iLoc is open-source and can be downloaded from https://seiscode.iris. washington.edu/projects/iloc.

\section{Declarations}

Conflict of interest The authors declare that they have no competing interests.

Availability of data and material The Hungarian SeismoAcoustic Bulletins are available for download at http://www. infrasound.hu/index.php/en/hungarian-seismo-acousticbulletin.

Open Access This article is licensed under a Creative Commons Attribution 4.0 International License, which permits use, sharing, adaptation, distribution and reproduction in any medium or format, as long as you give appropriate credit to the original author(s) and the source, provide a link to the Creative Commons licence, and indicate if changes were made. The images or other third party material in this article are included in the article's Creative Commons licence, unless indicated otherwise in a credit line to the material. If material is not included in the article's Creative Commons licence and your intended use is not permitted by statutory regulation or exceeds the permitted use, you will need to obtain permission directly from the copyright holder. To view a copy of this licence, visit http://creativecommons.org/licenses/by/4.0/.

\section{Appendix}

Summary of Detection Statistics of Quarry Blasts for the PSZI Infrasound Array. Mines are Ordered by their Distance from PSZI. Dabas is a Site Used to Detonate Spent Ammunition

\begin{tabular}{|c|c|c|c|c|c|c|c|}
\hline Mine & Latitude & Longitude & Distance & baz & All & Detected & Rate\% \\
\hline Gyöngyössolymos, HU & 47.83 & 19.93 & 10.64 & 162.94 & 16 & 14 & 88 \\
\hline Gyöngyöstarján, HU & 47.82 & 19.86 & 11.15 & 192.73 & 13 & 10 & 77 \\
\hline Recsk, HU & 47.90 & 20.09 & 15.09 & 98.96 & 29 & 25 & 86 \\
\hline Kisnána, HU & 47.87 & 20.15 & 20.59 & 107.18 & 25 & 18 & 72 \\
\hline Nagylóc, HU & 48.01 & 19.63 & 21.80 & 296.15 & 22 & 13 & 59 \\
\hline Siatorska-Bukovinka & 48.17 & 19.82 & 28.67 & 350.14 & 7 & 5 & 71 \\
\hline Szanda, HU & 47.92 & 19.41 & 35.97 & 269.31 & 12 & 10 & 83 \\
\hline Egerbakta, HU & 47.98 & 20.37 & 36.34 & 79.96 & 8 & 5 & 63 \\
\hline Bercel, HU & 47.89 & 19.40 & 36.40 & 265.27 & 13 & 9 & 69 \\
\hline Velke-Dravce, SK & 48.35 & 19.86 & 47.49 & 357.23 & 33 & 4 & 12 \\
\hline Sejce-Vác, HU & 47.84 & 19.13 & 57.84 & 260.93 & 50 & 24 & 48 \\
\hline Miskolc-Mexikóvölgy, HU & 48.08 & 20.70 & 62.79 & 73.77 & 12 & 2 & 17 \\
\hline Dunabogdány, HU & 47.78 & 19.04 & 65.72 & 256.53 & 5 & 5 & 100 \\
\hline Horne-Turovce, SK & 48.12 & 18.96 & 73.14 & 287.87 & 6 & 2 & 33 \\
\hline Krupina, SK & 48.40 & 19.08 & 80.74 & 312.11 & 14 & 4 & 29 \\
\hline Viglas, SK & 48.54 & 19.30 & 81.60 & 327.73 & 9 & 3 & 33 \\
\hline Tisovec, $\mathrm{Sk}$ & 48.69 & 19.95 & 85.49 & 2.76 & 5 & 1 & 20 \\
\hline Hontianske-Trstany, SK & 48.22 & 18.78 & 89.37 & 292.47 & 6 & 1 & 17 \\
\hline Dabas, HU & 47.17 & 19.31 & 94.13 & 208.01 & 18 & 10 & 56 \\
\hline Dvorniky-Vcelare, SK & 48.58 & 20.81 & 100.43 & 42.70 & 342 & 19 & 6 \\
\hline Etyek, HU & 47.47 & 18.70 & 102.69 & 241.14 & 9 & 6 & 67 \\
\hline Bersekbánya-I, HU & 47.72 & 18.52 & 104.59 & 258.36 & 6 & 0 & 0 \\
\hline Tállya, HU & 48.25 & 21.25 & 107.37 & 69.70 & 80 & 2 & 3 \\
\hline Tarcal, HU & 48.12 & 21.37 & 112.55 & 77.82 & 7 & 0 & 0 \\
\hline Tatabánya, HU & 47.56 & 18.46 & 114.66 & 250.10 & 41 & 8 & 20 \\
\hline Spisska-Nova-Ves, SK & 48.89 & 20.54 & 118.41 & 23.74 & 6 & 0 & 0 \\
\hline Hostie, SK & 48.45 & 18.44 & 122.64 & 299.14 & 7 & 4 & 57 \\
\hline Kamenec-pod-Vtacnikom, SK & 48.66 & 18.58 & 126.77 & 310.66 & 5 & 1 & 20 \\
\hline Gánt, HU & 47.36 & 18.40 & 128.06 & 241.67 & 147 & 17 & 12 \\
\hline Sárospatak, HU & 48.31 & 21.54 & 130.14 & 70.12 & 8 & 1 & 13 \\
\hline Magyaralmás, HU & 47.32 & 18.31 & 136.53 & 241.16 & 16 & 2 & 13 \\
\hline Trebejov, SK & 48.84 & 21.23 & 142.25 & 43.84 & 5 & 0 & 0 \\
\hline
\end{tabular}


continued

\begin{tabular}{|c|c|c|c|c|c|c|c|}
\hline Mine & Latitude & Longitude & Distance & baz & All & Detected & Rate \% \\
\hline Iszkaszentgyörgy, HU & 47.23 & 18.28 & 143.14 & 238.20 & 150 & 23 & 15 \\
\hline Vilonya, HU & 47.12 & 18.07 & 163.15 & 237.82 & 6 & 0 & 0 \\
\hline Litér, HU & 47.09 & 18.02 & 168.22 & 237.47 & 16 & 0 & 0 \\
\hline Királyszentistván, HU & 47.11 & 17.99 & 168.63 & 238.63 & 9 & 4 & 44 \\
\hline Ugod, HU & 47.33 & 17.64 & 181.74 & 249.68 & 22 & 3 & 14 \\
\hline Horne-Oresany, SK & 48.46 & 17.43 & 192.54 & 288.91 & 6 & 3 & 50 \\
\hline Rohoznik, SK & 48.45 & 17.21 & 207.94 & 287.30 & 19 & 3 & 16 \\
\hline Tetchea, RO & 47.00 & 22.30 & 208.56 & 118.55 & 13 & 6 & 46 \\
\hline Nagymányok, HU & 46.27 & 18.45 & 214.03 & 211.26 & 6 & 1 & 17 \\
\hline Hainburg. A & 48.13 & 16.91 & 223.22 & 277.20 & 34 & 7 & 21 \\
\hline Komló, HU & 46.18 & 18.29 & 228.69 & 212.64 & 69 & 12 & 17 \\
\hline Várvölgy, HU & 46.85 & 17.27 & 230.55 & 240.06 & 21 & 8 & 38 \\
\hline Bükkösd, HU & 46.13 & 18.02 & 245.17 & 216.23 & 81 & 17 & 21 \\
\hline Poieni, RO & 46.91 & 22.86 & 250.72 & 115.57 & 11 & 2 & 18 \\
\hline Nagyharsány, HU & 45.85 & 18.40 & 256.43 & 206.88 & 15 & 2 & 13 \\
\hline Beremend, HU & 45.79 & 18.44 & 260.97 & 205.56 & 6 & 1 & 17 \\
\hline Rosia-Poieni, RO & 46.32 & 23.18 & 306.73 & 124.22 & 18 & 1 & 6 \\
\hline Baita, RO & 46.03 & 22.86 & 308.73 & 131.84 & 16 & 1 & 6 \\
\hline Sum & & & & & 1500 & 319 & 21 \\
\hline
\end{tabular}

Publisher's Note Springer Nature remains neutral with regard to jurisdictional claims in published maps and institutional affiliations.

\section{REFERENCES}

Blandford, R. (1977). Discrimination between earthquakes and underground explosions. Annual Review of Earth and Planetary Sciences, 5, 111-122

Bondár I., Czanik, Cs., Czecze, B., Kalmár, D., Kiszely, M., Mónus, P. \& Süle, B. (2019). Hungarian Seismo-Acoustic Bulletin 2017-2018, ed: I. Bondár, ISSN: 2676-7902, MTA CSFK GGI Kövesligethy Radó Szeizmológiai Obszervatórium, Budapest.

Bondár I., Czanik, Cs., Czecze, B., Kalmár, D., Kiszely, M., Mónus, P. \& Süle, B. (2020). Hungarian Seismo-Acoustic Bulletin 2019, ed: I. Bondár, ISSN: 2676-7902, CSFK GGI Kövesligethy Radó Szeizmológiai Obszervatórium, Budapest.

Bondár, I., \& McLaughlin, K. (2009). Seismic location bias and uncertainty in the presence of correlated and non-Gaussian travel-time errors. Bulletin of the Seismological Society of America, 99, 172-193

Bondár, I., Mónus, P., Czanik, C., Kiszely, M., Gráczer, Z., Wéber, Z., \& the AlpArrayWorking Group. (2018). Relocation of seismicity in the Pannonian basin using a global 3D velocity model. Seismological Research Letters, 89, 2284-2293

Bondár, I., \& Storchak, D. (2011). Improved location procedures at the International Seismological Centre. Geophysical Journal International, 186, 1220-1244
Bowers, D., \& Selby, N. (2009). Forensic seismology and the comprehensive nuclear-test-ban treaty. Annual Review of Earth and Planetary Sciences, 37, 209-236

Cansi, Y. (1995). An automatic seismic event processing for detection and location: the P.M.C.C. method. Geophysical Research Letters, 22, 1021-1024

Che, I. Y., Park, J., Kim, T. S., Hayward, C., \& Stump, B. (2019). On the use of a dense network of seismo-acoustic arrays for nearregional environmental monitoring. In A. Le Pichon, E. Blanc, \& A. Hauchecorne (Eds.), Infrasound monitoring for atmospheric studies. (2nd ed., pp. 409-448). Springer.

Che, I. Y., Stump, B. W., \& Hee-Il, L. (2011). Experimental characterization of seasonal variations in infrasonic travel times on the Korean Peninsula with implications for infrasound event location. Geophysical Journal International, 185, 190-200

Czanik C., Ghica D., Sindelarova T., Mitterbauer U. (2019). Improving the infrasound monitoring capability in europe incorporating CEEIN, T1.1-P16, CTBT SnT 2019 conference, Vienna, June 24-28, 2019.

Drob, D. P., Picone, J. M., \& Garcés, M. (2003). Global morphology of infrasound propagation. Journal of Geophysical Research: Atmospheres, 108, 4680

Ford, S. R., \& Walter, W. R. (2015). International Monitoring System correlation detection at the North Korean nuclear test site at Punggye-ri with insights from the Source Physics Experiment. Seismological Research Letters, 86, 1160-1170

Fuchs, F., Schneider, F. M., Kolinsky, P., Serafin, S., \& Bokelmann, G. (2019). Rich observations of local and regional infrasound phases made by the AlpArray seismic network after refinery explosion. Scientific Reports, 9, 13027

Gibbons, S., Kværna, T., \& Näsholm, P. (2019). Characterization of the infrasonic wavefield from repeating seismo-acoustic events. In A. Le Pichon, E. Blanc, \& A. Hauchecorne (Eds.), 
Infrasound monitoring for atmospheric studies. (2nd ed., pp. 387-407). Springer.

Gibbons, S. J., Ringdal, F., \& Kværna, T. (2007). Joint seismicinfrasonic processing of recordings from a repeating source of atmospheric explosions. Journal of the Acoustical Society of America, 122, EL158-EL164

Gráczer, Z. I. Bondár, Cs. Czanik, T. Czifra, E. Gyori, M. Kiszely, P. Mónus, B. Süle, Gy. Szanyi, L. Tóth, P. Varga, V. Wesztergom, \& Z. Wéber (2018). Hungarian National Seismological Bulletin 2017, ed: Z. Gráczer, MTA CSFK GGI Kövesligethy Radó Szeizmológiai Obszervatórium, Budapest.

Gráczer, Z., Bondár, I., Czanik, Cs. Czifra, T., Gyori, E., Kiszely, M., Kovács, I. J., Mónus, P., Süle, B., Szanyi, Gy., Topa, Zs., Tóth, L., Varga, P., Wesztergom, V. Wéber, Z. (2019). Hungarian National Seismological Bulletin 2018, ed: Z. Gráczer, CSFK GGI Kövesligethy Radó Szeizmológiai Obszervatórium, Budapest.

Kereszturi, A., Barta, V., Bondár, I., Czanik, Cs., Igaz, A., Mónus, P., \& Pál, B. (2020). Connecting ionospheric, optical, infrasound and seismic data from meteors in Hungary. WGN Journal of the International Meteor Organization, 48, 188-192

Kintner, J. A. K. M., Cleveland, C. J. A., \& Nyblade, A. (2020). Testing a local-distance $\mathrm{Rg} / \mathrm{Sg}$ discriminant using observations from the Bighorn region, Wyoming. Bulletin of the Seismological Society of America, 110, 727-741

Koch, K., \& Pilger, C. (2020). A comprehensive study of infrasound signals detected from the Ingolstadt, Germany, explosion of 1 September 2018. Pure and Applied Geophysics, 177, 4229-4245

Koch, K., Pilger, C., Czanik, C., \& Bondár, I. (2020). The 12 December 2017 Baumgarten Gas Hub explosion: a case study on understanding the occurrence of a large infrasound azimuth residual and a lack of seismic observations. Pure and Applied Geophysics, 177, 4957-4970

Kulichkov, S.N., (2000). On infrasonic arrivals in the zone of geometric shadow at long distances from surface explosions, in Proceedings of the Ninth Annual Symposium on Long-Range Propagation, Oxford, Mississippi, 14-15 September, National Center for Physical Acoustics, 238-251.

Le Pichon, A., Ceranna, L., \& Vergoz, J. (2012). Incorporating numerical modeling into estimates of the detection capability of the IMS infrasound network. Journal of Geophysical Research, 117, D05121
Le Pichon, A., Vergoz, J., Herry, P., \& Ceranna, L. (2008). Analyzing the detection capability of infrasound arrays in Central Europe. Journal of Geophysical Research, 113, D12115

Negraru, P. T., Golden, P., \& Herrin, E. T. (2010). Infrasound propagation in the "Zone of Silence." Seismological Research Letters, 81, 614-624

Nippress, A., Green, D. N., Marcillo, O. E., \& Arrowsmith, S. J. (2014). Generating regional infrasound celerity-range models using ground-truth information and the implications for event location. Geophysical Journal International, 197, 1154-1165

O'Rourke, C. T., Baker, G. E., \& Sheehan, A. F. (2016). Using P/S amplitude ratios for seismic discrimination at local distances. Bulletin of the Seismological Society of America, 106, 2320-2331

Pásztor M., Czanik, Cs., Bondár, I. (2020). Identitification and tracking of storms via infrasound detections, EGU General Assembly 2020, Online, 4-8 May 2020, EGU2020-446. https:// doi.org/10.5194/egusphere-egu2020-446

Pilger, C., Ceranna, L., Ross, J. O., Vergoz, J., Le Pichon, A., Brachet, N., Blanc, E., Kero, J., Liszka, L., Gibbons, S., Kvaerna, T., Näsholm, S. P., Marchetti, E., Ripepe, M., Smets, P., Evers, L., Ghica, D., Ionescu, C., Sindelarova, T., ... Mialle, P. (2018). The European infrasound bulletin. Pure and Applied Geophysics, 175, 3619-3638

Richards, P. G., \& Zavales, J. (1990). Seismic discrimination of nuclear explosions. Annual Review of Earth and Planetary Sciences, 18, 257-286

Schneider, F. M., Fuchs, F., Kolínský, P., Caffagni, E., Serafin, S., Dorninger, M., Bokelmann, G., \& the AlpArray Working Group. (2018). Seismo-acoustic signals of the Baumgarten (Austria) gas explosion detected by the AlpArray seismic network. Earth and Planetary Science Letters, 502, 104-114

Smets, P. S. M., Evers, L. G., Näsholm, S. P., \& Gibbons, S. J. (2015). Probabilistic infrasound propagation using realistic atmospheric perturbations. Geophysical Research Letters, 42, 6510-6517

Sorrells, G. G., Herrin, E. T., \& Bonner, J. L. (1997). Construction of regional ground truth databases using seismic and infrasound data. Seismological Research Letters, 68, 743-752

Stump, B. W., Hedlin, M. A. H., Pearson, D. C., \& Hsu, V. (2002). Characterization of mining explosions at regional distances: Implications with the International Monitoring System. Reviews of Geophysics, 40, 1011 